\title{
OPEN Determination of mercury thermospecies in South African coals in the enhancement of mercury removal by pre-combustion technologies
}

\author{
Mpho Wendy Mathebula, Nikolai Panichev \& Khakhathi Mandiwana
}

Samples of South African bituminous coals were analysed for total mercury $(\mathrm{Hg})$ and $\mathrm{Hg}$ thermospecies concentrations using an RA-915 + Zeeman Mercury Analyser. Total mercury concentrations in samples of coals $(n=57)$ ranged between $10 \mathrm{ng} \mathrm{g}^{-1}$ and $493 \mathrm{ng} \mathrm{g}^{-1}$ with a mean value of $150 \pm 53 \mathrm{ng} \mathrm{g}^{-1}$. Thermospecies of $\mathrm{Hg}$ were determined by monitoring $\mathrm{Hg}$ response as a function of sample temperature, increasing at $0.8^{\circ} \mathrm{C} / \mathrm{s}$ from ambient to $720^{\circ} \mathrm{C}$. This approach provides important information on thermal release of $\mathrm{Hg}$ species, as indicated by their appearance over specific temperature intervals. This permits identification of the presence of $\mathrm{Hg}$ thermospecies in coal and their quantification in each time (temperature) interval. It was found that $76 \%$ of tested bituminous coal samples release $\mathrm{Hg}$ species within low temperature intervals $\left(20-180^{\circ} \mathrm{C}\right.$ and $\left.180-360^{\circ} \mathrm{C}\right)$. The information generated in this study will aid in the selection of suitable coals for pre-combustion treatment that can lead to significant reduction of atmospheric $\mathrm{Hg}$ emission during coal combustion at power stations. This analytical approach can also be used for the creation of a system of coal classification based on the temperature of release of various $\mathrm{Hg}$ thermospecies.

The increasing concentration of mercury $(\mathrm{Hg})$ in the environment, both from natural and anthropogenic sources, is a global problem that poses risk to the health of humans and wildlife ${ }^{1-3}$. Mercury is transported around the globe as gaseous elemental mercury $\left(\mathrm{Hg}^{0}\right)$; therefore, its emission into the atmosphere poses hazardous consequences even in remote locations ${ }^{4}$. Exposure to mercury elicits a range of negative health effects ${ }^{5}$ and is recognized by the World Health Organization (WHO) as a harmful chemical due to its high toxicity, volatility and bioaccumulation ${ }^{6}$.

At present, the major sources of anthropogenic Hg emission are small scale gold production (SCGP) and coal combustion at electrical power stations and industrial boilers ${ }^{7-9}$. Mercury emissions from coal combustion take place mostly in the form of gaseous elemental mercury $\left(\mathrm{Hg}^{0}\right)$, with small amounts of gaseous oxidized mercury $\left(\mathrm{Hg}^{2+}\right)$, and particulate-bound mercury $\left(\mathrm{Hg}_{\mathrm{p}}\right)$. Methyl mercury is the most toxic organic mercury compound, commonly accumulating in fish and via the food chain can accumulate in mammals and humans to a very high toxic level. The most serious case of $\mathrm{MeHg}$ poisoning from contaminated fish took place in 1956 in Minamata, Japan ${ }^{10}$. The MeHg poisoning of humans, known as Minamata disease, united the world community in an effort to reduce global $\mathrm{Hg}$ pollution by creation of the United Nations Minamata Convention on mercury ${ }^{11}$. The role of the Minamata Convention is to protect human health and the environment from anthropogenic emissions that release mercury and mercury compounds to the atmosphere. Signatories of the Convention, which include major industrialized countries, such as China, USA, European Union (EU), Russia, India, Brazil and South Africa, have committed themselves to play a major role in this reduction program ${ }^{12}$.

Data on the inventory of global mercury emissions for 2015 show that approximately $5000 \mathrm{t}$ of $\mathrm{Hg}$ originated from natural sources whereas $2220 \mathrm{t}$ arose from anthropogenic sources. Artisanal and small-scale gold mining (ASGM) contributed $725 \mathrm{t}(32.7 \%)$ and coal combustion, mostly from electricity generation, contributed $474 \mathrm{t}$ (21\%) of the annual anthropogenic discharge ${ }^{13}$. The highest amount of $\mathrm{Hg}$ entering the atmosphere from coal combustion $(250 \mathrm{t})$ took place in China ${ }^{14}$. 
Coal combustion during electricity generation is the main source of $\mathrm{Hg}$ emission to the South African atmosphere ${ }^{15}$. Exact data on the amount of $\mathrm{Hg}$ emitted was acquired only after several controversial publications. Thus, according to Pacyna et al. ${ }^{16}$, the amount of emitted Hg in South Africa in 2000 was 50 t. Recalculated data reported by Dabrowski et al. ${ }^{17}$ showed a much smaller number $(9.8 \mathrm{t})$ but data reported by Masekoameng et al. ${ }^{18}$ was three-fold higher $(29.47 \mathrm{t})$. Garnham and Langerman $(2016)^{19}$ subsequently showed that the amount of $\mathrm{Hg}$ from coal combustion in South Africa could range between 16 and $20 \mathrm{t} /$ annum. Such differences may arise simply from uncertainty in the results of analytical determinations of the $\mathrm{Hg}$ content in coals.

In order to reduce $\mathrm{Hg}$ emissions from coal combustion, it was recommended that only coal having lower $\mathrm{Hg}$ content should be used ${ }^{20}$. Reduction during coal combustion is possible by preliminary cleaning, either by washing or by thermal treatment prior to combustion ${ }^{21-25}$. Coal washing removes the $\mathrm{Hg}$ associated with incombustible mineral materials such as pyrite $\left(\mathrm{FeS}_{2}\right)$ and thus reduces ash content to improve coal heating value. Some coals contain large amounts of $\mathrm{Hg}$ associated with their organic fraction and this can be a setback as it cannot be removed by coal washing. Therefore, controlled pyrolysis of coal provides a more promising alternative for mercury removal from all types of coals prior to combustion. However, the rate of mercury removal is affected by the treatment temperature, heating time, sweep gas flow and especially by the forms of mercury present. The efficiency of such thermal cleaning will be greatest in coal containing highly volatile $\mathrm{Hg}$ species. Mercury compounds that decompose at high temperature require much higher energy to release $\mathrm{Hg}$ species from coal. Such coal should be characterized in advance of its combustion to identify the most suitable pre-treatment temperature for removal of $\mathrm{Hg}^{26,27}$.

South Africa, as a signatory to the Minamata Convention is required (under Article 8), to reduce $\mathrm{Hg}$ emissions from coal-fired power plants during electricity generation ${ }^{11,28}$. The present study was initiated to develop analytical methods capable of identifying coals that contain $\mathrm{Hg}$ species having low volatilization temperatures such that they can undergo appropriate pre-combustion treatment. A new coal classification system could also be created based on the temperature of release of various $\mathrm{Hg}$ species. Such a classification system would be useful in identifying the effective pre-combustion and pre-gasification coal treatment method for reduction of $\mathrm{Hg}$ in coal prior to its combustion.

\section{Experimental}

Instrumentation. A RA-915 + Zeeman mercury analyzer (Lumex, St. Petersburg, Russia) was used for the quantification of various $\mathrm{Hg}$ species in coal samples. The working principle of the Zeeman mercury analyzer has been detailed by Sholupov et al. (2004) $)^{29}$ and is based on the thermal desorption of $\mathrm{Hg}$ from solid coal samples followed by the detection of $\mathrm{Hg}$ atoms by atomic absorption. Background absorption is eliminated by the use of a high frequency Zeeman correction system ${ }^{30}$. The concentration of $\mathrm{Hg}$ in the sample is determined from a calibration curve plotted as integrated analytical signal (arbitrary units) versus absolute mass of $\mathrm{Hg}$ (ng). Realtime measurement of $\mathrm{Hg}$ during its thermal release from samples is accomplished within $60-100 \mathrm{~s}$ at a resolution of one second (1s).

Samples. Samples of coals $(n=57)$ were collected from coal mines of Gauteng, Limpopo, Mpumalanga, Free State, KwaZulu-Natal and Eastern Cape Provinces of South Africa following a standard method for obtaining representative samples ${ }^{31}$. Coal production in South Africa is concentrated in the Highveld region of Mpumalanga Province where the Witbank, Highveld, and Ermelo coals are produced ${ }^{32,33}$. The mined coal is usually supplied to Eskom (Electricity Supply Commission) power stations for power generation and Sasol (abbreviated from Afrikaans Suid Afrikaanse Steenkool en Olie Maatskappy, literally translated as South African Coal and Oil Company in English) for use as feedback for the production of liquid fuel and chemicals and the surplus stock of coal is exported. The coal reserves in Witbank, Highveld and Waterberg (Limpopo Province) constitute approximately $70 \%$ of South Africa's recoverable coal reserves ${ }^{34}$. The Witbank and Highveld coals are laterally contiguous as coal types as different characteristics coexist in the same coal beds.

Analytical procedure for determination of total Hg. For the determination of total $\mathrm{Hg}$, thermal decomposition of pulverized accurately weighted (to nearest $\mathrm{mg}$ ) sub-samples was undertaken. The weighed sample was placed in a pre-cleaned quartz sampling boat and inserted into the furnace of the $\mathrm{Hg}$ analyser. The exact weight of the sample, ranging between 200 and $300 \mathrm{mg}$, was recorded using the RAPID software. Determination of total $\mathrm{Hg}$ was accomplished by heating samples until complete evaporation of $\mathrm{Hg}$ was ensured, usually within 60 to $100 \mathrm{~s}$ at $0.8^{\circ} \mathrm{C} / \mathrm{s}$ from ambient to $720^{\circ} \mathrm{C}$. Software permits temporal evolution of the analytical peak (Hg absorption) to be followed with the area under the peak, the maximum absorbance value and calculated concentration to be displayed. Each sample of coal was analysed in triplicate and results reported as a mean \pm standard deviation of $\mathrm{Hg}$ concentration.

\section{Results}

Calibration of the mercury analyser. The mercury analyser was calibrated using certified reference materials (CRMs) containing Hg content in the range covered in the coal samples. Standard SARM 20 (MINTEK, South Africa, $250 \pm 30 \mathrm{ng} \mathrm{g}^{-1}$ ) and PACS-2 (National Council of Canada, Canada, $3040 \pm 99 \mathrm{ng} \mathrm{g}^{-1}$ ) were used for instrument calibration while CRM 7002 (Light sandy soil; Czech Republic, $90 \pm 5 \mathrm{ng} \mathrm{g}^{-1}$ ) and CRM 024-050 (Loam soil 1, $710 \pm 50 \mathrm{ng} \mathrm{g}^{-1}$ ) were used for method validation.. A calibration curve, plotted as integrated absorbance (peak area, arbitrary units) versus absolute mass of $\mathrm{Hg}(\mathrm{ng})$ defined by a typical regression equation such as $y=350 x-71$ was obtained and used for the quantification of $\mathrm{Hg}$. The calibration curve was linear $\left(\mathrm{R}^{2}=0.998\right)$ up to $800 \mathrm{ng}$ of $\mathrm{Hg}$. This absolute value of $800 \mathrm{ng} \mathrm{Hg}$ indicates that the relative $\mathrm{Hg}$ concentration that can be determined in coal with acceptable precision and accuracy is $3200 \mathrm{ng} \mathrm{g}^{-1}$ for a sample mass of $250 \mathrm{mg}$. Therefore, 


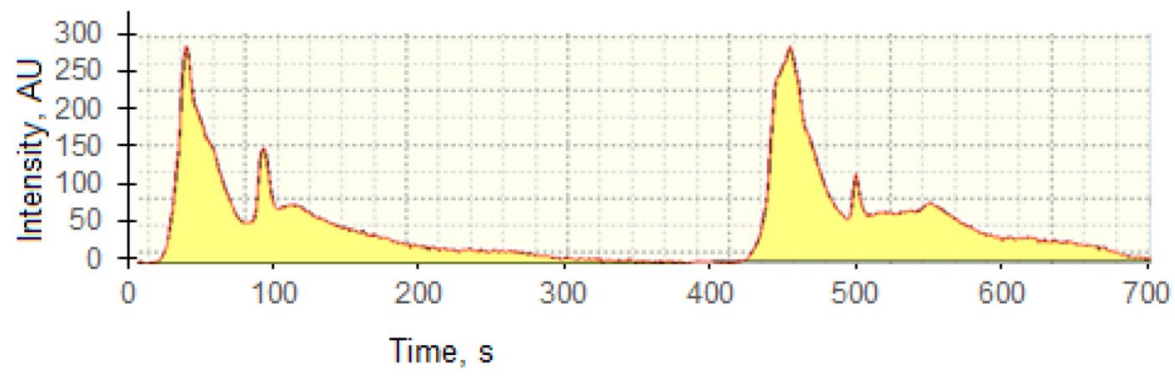

Figure 1. Reproducibility of $\mathrm{Hg}$ thermopeaks measurement.

\begin{tabular}{|c|c|c|c|c|c|c|c|c|}
\hline \multirow[b]{2}{*}{ Measurements number } & \multicolumn{2}{|l|}{ Coal MH-3 } & \multicolumn{2}{|l|}{ Coal FS-5 } & \multicolumn{2}{|l|}{ Coal S2 } & \multicolumn{2}{|l|}{ Coal-G1 } \\
\hline & $\leq 0.05 \mathrm{~mm}$ & $1-3 \mathrm{~mm}$ & $\leq 0.05 \mathrm{~mm}$ & $1-3 \mathrm{~mm}$ & $\leq 0.05 \mathrm{~mm}$ & $1-3 \mathrm{~mm}$ & $\leq 0.05 \mathrm{~mm}$ & $1-3 \mathrm{~mm}$ \\
\hline 1 & 138 & 155 & 273 & 448 & 477 & 523 & 433 & 390 \\
\hline 2 & 143 & 141 & 255 & 151 & 468 & 506 & 430 & 425 \\
\hline 3 & 147 & 129 & 279 & 253 & 480 & 413 & 434 & 466 \\
\hline 4 & 144 & 132 & 248 & 145 & 475 & 458 & 429 & 416 \\
\hline 5 & 135 & 137 & 290 & 265 & 482 & 482 & 432 & 388 \\
\hline 6 & 136 & 145 & 285 & 233 & 488 & 435 & 435 & 450 \\
\hline 7 & 145 & 143 & 256 & 402 & 458 & 518 & 428 & 472 \\
\hline Mean \pm SD & $141 \pm 5$ & $140 \pm 9$ & $269 \pm 16$ & $271 \pm 116$ & $475 \pm 10$ & $476 \pm 43$ & $432 \pm 3$ & $430 \pm 34$ \\
\hline RSD (\%) & 3.5 & 6.4 & 5.9 & 42.8 & 2.1 & 9.0 & 1.0 & 7.9 \\
\hline
\end{tabular}

Table 1. Results of $\mathrm{Hg}$ determination in coal of variable particle sizes, $\mathrm{ng} \mathrm{g}^{-1}$.

this analytical approach based on thermal decomposition to determine the $\mathrm{Hg}$ content in coal is more favourable than chemical decomposition methods as it is more rapid and offers high efficiency.

In general, results for determination of $\mathrm{Hg}$ in the CRMs were in good agreement with certified concentration values at 95\% level of confidence as the found values in SARM 20, PACS-2, CRM 7002 and CRM024-050 were $248 \pm 7 \mathrm{ng} \mathrm{g}^{-1}, 2990 \pm 110 \mathrm{ng} \mathrm{g}^{-1}, 94 \pm 8 \mathrm{ng} \mathrm{g}^{-1}$ and $718 \pm 14 \mathrm{ng} \mathrm{g}^{-1}$, respectively. To check the reproducibility of the analytical method, replicate samples of coal were analysed as shown in Fig. 1. The long-term results of Hg measurements $(n=33)$ were within the confidence intervals of certified values at the $95 \%$ confidence level.

Limit of detection and limit of quantification. Due to a lack of "blank" coal samples on the market, the determination of the limits of detection (LOD) and quantification (LOQ) were calculated from the regression line of the calibration curve presented in a general form: $y=a+b x$. Numerical calculations were performed using the following formulas: $L O D=a+3 S_{a} / b$ and $L O Q=a+10 S_{a} / b$, where $S_{a}$ is the standard deviation of the response $y$ and $b$ is the slope of calibration curve ${ }^{35}$. The LOD and LOQ were found to be $0.3 \mathrm{ng}$ and $1.0 \mathrm{ng}$, respectively. These values indicate that for a coal sample of $250 \mathrm{mg}$ the relative LOD is $1.20 \mathrm{ng} \mathrm{g}^{-1}$ and the LOQ is $4.0 \mathrm{ng} \mathrm{g}^{-1}$, illustrating that the methodology is capable of determining $\mathrm{Hg}$ content in coals of any commercial use.

Influence of coal particles size on the results of $\mathrm{Hg}$ determination. The first factor to be evaluated during method development was the influence of particle size on the accuracy and precision of the results. This was achieved by analysing coal samples with particle sizes in the range $1-3 \mathrm{~mm}(1000-3000 \mu \mathrm{m})$ and pulverized coal with particle sizes of less than $50 \mu \mathrm{m}$. It was found that the results of the determination mercury in coals having a uniform distribution of $\mathrm{Hg}$ were not influenced by the particle size, as evident in Table 1 .

This conclusion follows from a comparison of values of the relative standard deviation (RSD), which in the case of large particle size, RSD ranged between $6.4 \%$ and $42.8 \%$, while for samples with small particle size, it was $1 \%-5.9 \%$. Coal samples with inhomogeneous distribution of $\mathrm{Hg}$ can be analysed with good precision $(\mathrm{RSD}=6 \%)$ only if particle size is first reduced. For samples having particle size 1000-3000 $\mu \mathrm{m}$ or higher, an RSD of as high as $42.8 \%$ could be reached. Results of this study suggest that coal samples should be ground to a particle size of $50 \mu \mathrm{m}$ or lower to achieve higher accuracy and precision for coal with any kind of $\mathrm{Hg}$ distribution.

Influence of sample mass on quantification of $\mathrm{Hg}$. The second factor evaluated was the influence of sample mass on the results of determination of total Hg. For this purpose, coal standard SARM 20 and ordinary coal samples were used and the results are displayed in Fig. 2. For coal G1, masses of $77 \mathrm{mg}, 140.4 \mathrm{mg}$ and $305 \mathrm{mg}$ yielded $441 \mathrm{ng} \mathrm{g}^{-1}, 426 \mathrm{ng} \mathrm{g}^{-1}$ and $431 \mathrm{ng} \mathrm{g}^{-1}$, respectively, with mean concentration of $433 \pm 8 \mathrm{ng} \mathrm{g}^{-1}$, irrespective of the sample mass taken for analysis. Similarly, for SARM 20, masses of $74.5 \mathrm{mg}, 158.6 \mathrm{mg}$ and $250.3 \mathrm{mg}$ yielded 

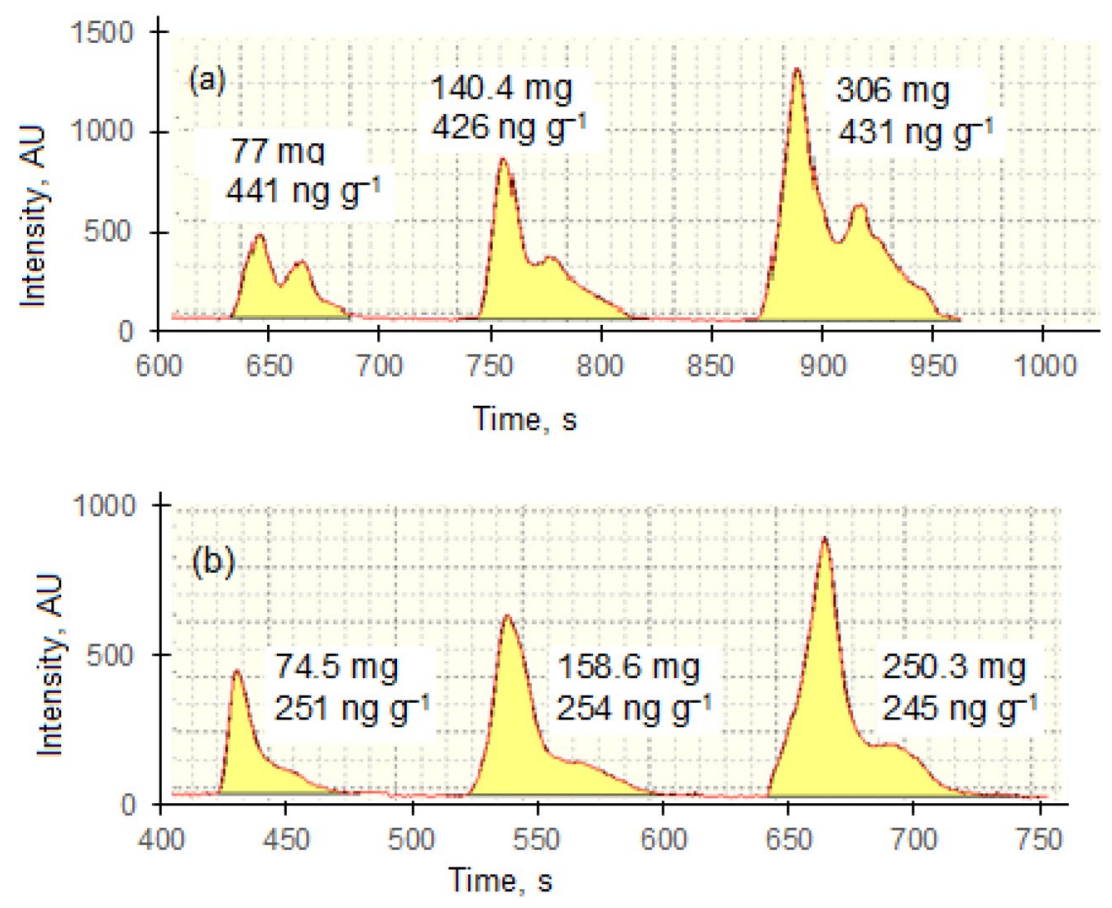

Figure 2. Results of subsample mass influence on Hg peak: (a) Coal G1; (b) SARM-20.

\begin{tabular}{|l|l|l|l|l|}
\hline \multirow{2}{*}{ Mass of coal, $\mathbf{m g}$} & \multicolumn{5}{|l|}{ Concentration of Hg in coal, $\mathbf{n g ~ g}^{-\mathbf{1}}$} \\
\cline { 2 - 5 } & Coal MH-3 & Coal FS-5 & Coal S2 & Coal-G1 \\
\hline 50 & 143 & 280 & 510 & 436 \\
\hline 100 & 139 & 264 & 480 & 428 \\
\hline 150 & 148 & 270 & 485 & 433 \\
\hline 200 & 140 & 277 & 471 & 430 \\
\hline 250 & 145 & 272 & 491 & 439 \\
\hline 300 & 138 & 269 & 455 & 426 \\
\hline Mean \pm SD & $142 \pm 4$ & $272 \pm 6$ & $480 \pm 20$ & $432 \pm 5$ \\
\hline RSD $(\%)$ & 2.8 & 2.2 & 4.2 & 1.0 \\
\hline
\end{tabular}

Table 2. Results of Hg determination in coal samples of variable masses.

$251 \mathrm{ng} \mathrm{g}^{-1}, 254 \mathrm{ng} \mathrm{g}^{-1}$ and $245 \mathrm{ng} \mathrm{g}^{-1}$, respectively, with a mean $\mathrm{Hg}$ concentration of $250 \pm 5 \mathrm{ng} \mathrm{g}^{-1}$ irrespective of rising sample masses. Similarly, quantitative results of $\mathrm{Hg}$ determination in four coal samples analysed in assessment of coal particle confirmed that sample mass of $50 \mathrm{mg}$ to $300 \mathrm{mg}$ has no influence on either the reproducibility of $\mathrm{Hg}$ concentration as shown by relative standard deviations that ranged between 1.0 and $4.2 \%$ (Table 2). Therefore, it can be concluded that the results for determination of total $\mathrm{Hg}$ in coal are independent of sample mass taken for analysis.

Total Hg concentration in coals. Results for determination of total $\mathrm{Hg}$ in individual coals samples from South African Provinces, viz., Gauteng, Limpopo, Mpumalanga and KwaZulu-Natal and Free State, show high variability in concentration and range from 10 to $493 \mathrm{ng} \mathrm{g}^{-1}$ as shown in Table 3.

The mean concentration varied from 68 to $230 \mathrm{ng} \mathrm{g}^{-1}$. Thus, the average $\mathrm{Hg}$ concentration in Mpumalanga's coal fields of Highveld and Witbank were found to be $158 \pm 22 \mathrm{ng} \mathrm{g}^{-1}$ and $115 \pm 60 \mathrm{ng} \mathrm{g}^{-1}$, respectively. The mean $\mathrm{Hg}$ content in coal from Highveld deposit is in agreement with the average of $150 \pm 50 \mathrm{ng} \mathrm{g}^{-1}$ reported by Wagner and Hlatshwayo ${ }^{36}$. The mean values of $\mathrm{Hg}$ content in coals Gauteng coal mines were found to be $180 \pm 150 \mathrm{ng} \mathrm{g}^{-1}$ and compare well with the average of $200 \mathrm{ng} \mathrm{g}^{-1}$ found in Gauteng coals as reported by Bergh ${ }^{37}$. The lowest mean $\mathrm{Hg}$ content of $68 \mathrm{ng} \mathrm{g}^{-1}$ was determined in Eastern Cape coals and the highest mean $\mathrm{Hg}$ content of $230 \mathrm{ng} \mathrm{g}^{-1}$ was found in Free State Province. An abnormally high $\mathrm{Hg}$ concentration of $2514 \mathrm{ng} \mathrm{g}^{-1}$ was measured in one coal sample from Mpumalanga Province and is statistically different from all other results, but matches the result of $2430 \mathrm{ng} \mathrm{g}^{-1}$ measured in coal from Vryheid formation ${ }^{38}$. The mean value of $\mathrm{Hg}$ concentration in coal samples from all South African Provinces was found to be $150 \pm 53 \mathrm{ng} \mathrm{g}^{-1}$. 


\begin{tabular}{|l|l|l|l|l|l|}
\hline Number & Province & Coal deposit & Number of samples & Concentration range, $\mathbf{n g ~ g}^{-1}$ & Mean \pm SD, $\mathbf{n g ~ g}^{-\mathbf{1}}$ \\
\hline 1 & Limpopo & Waterberg & 6 & $35-275$ & $120 \pm 95$ \\
\hline 2 & Mpumalanga & Highveld & 7 & $141-183$ & $158 \pm 22$ \\
\hline 3 & Mpumalanga & Witbank & 15 & $38-159$ & $115 \pm 60$ \\
\hline 4 & Gauteng & Vereeniging & 5 & $10-250$ & $180 \pm 150$ \\
\hline 5 & Free State, Vaal & New Vaal & 7 & $69-432$ & $230 \pm 298$ \\
\hline 6 & KwaZulu-Natal & Vryheid & 5 & $45-493$ & $182 \pm 42$ \\
\hline 7 & Eastern Cape & Ecca & 12 & $28-128$ & $68 \pm 33$ \\
\hline Total & & & 57 & - & $150 \pm 53$ \\
\hline
\end{tabular}

Table 3. Results of Hg determination in coals of South African Provinces.

\begin{tabular}{|c|c|c|c|c|}
\hline Coal sample batch \# & Type of Hg & Sample description & [Total Hg], $\mathrm{ng} \mathrm{g}^{-1}$ & Mean \pm SD, ng g $^{-1}$ \\
\hline \multirow{11}{*}{ Batch 1} & \multirow{3}{*}{ Organic bound } & WC-f1.40 & $817 \pm 12$ & \\
\hline & & WC-f1.45 & $561 \pm 20$ & \multirow{2}{*}{$583 \pm 224$} \\
\hline & & WC-f1.50 & $371 \pm 24$ & \\
\hline & \multirow{7}{*}{ Clay bound } & WC-f1.60 & $96 \pm 1$ & \multirow{7}{*}{$50 \pm 27$} \\
\hline & & WC-f1.70 & $71 \pm 1$ & \\
\hline & & WC-f1.75 & $50 \pm 2$ & \\
\hline & & WC-f1.80 & $49 \pm 2$ & \\
\hline & & WC-f1.85 & $43 \pm 3$ & \\
\hline & & WC-f1.90 & $23 \pm 1$ & \\
\hline & & WC-f2.00 & $20 \pm 1$ & \\
\hline & Mineral bound & WC-Sink & $79 \pm 2$ & $79 \pm 2$ \\
\hline \multirow{7}{*}{ Batch 2} & \multirow{3}{*}{ Organic bound } & GC-f1.4 & $44 \pm 1$ & \multirow{3}{*}{$34 \pm 11$} \\
\hline & & GC-f1.45 & $34 \pm 1$ & \\
\hline & & GC-f1.5 & $23 \pm 4$ & \\
\hline & \multirow{3}{*}{ Clay bound } & GC-f1.6 & $37 \pm 1$ & \multirow{3}{*}{$26 \pm 11$} \\
\hline & & GC-f1.7 & $26 \pm 2$ & \\
\hline & & GC-f1.9 & $15 \pm 1$ & \\
\hline & Mineral bound & GC-Sink & $1340 \pm 35$ & $1340 \pm 35$ \\
\hline
\end{tabular}

Table 4. Total Hg determination in density fractionated coal samples. WC Witbank coal, GC Gauteng coal.

Total $\mathrm{Hg}$ in density fractionated coal samples. Density fractionated coal samples were analysed in order to identify the fraction of coal with reference to its specific gravity that has the highest $\mathrm{Hg}$ content. Two batches of selected coal samples from Witbank and Gauteng mines were used for study. Fractions of coals, separated by densities ranging between $1.40 \mathrm{~g} \mathrm{~cm}^{-3}$ and $2.00 \mathrm{~g} \mathrm{~cm}^{-3}$, were analysed for the $\mathrm{Hg}$ concentration and results summarized in Table 4 .

For Witbank coals, the batch consisted of coal float samples, viz., WC-f1.40 to WC-fl2.0 and WC-Sink. It was found that low density float fractions contain more $\mathrm{Hg}\left(371 \pm 24 \mathrm{ng} \mathrm{g}^{-1}, 561 \pm 20 \mathrm{ng} \mathrm{g}^{-1}\right.$ and $\left.817 \pm 12 \mathrm{ng} \mathrm{g}^{-1}\right)$ with total average of $583 \pm 224 \mathrm{ng} \mathrm{g}^{-1}$ bound to organic fractions. Coal sink sample, WC-Sink, from this batch was found to contain only $79 \mathrm{ng} \mathrm{g}^{-1}$. For Gauteng coals, an average $\mathrm{Hg}$ content in coal float samples of low densities bound to organic compounds were found to be $34 \mathrm{ng} \mathrm{g}^{-1}$ while the mineral fraction of sink sample presented $1340 \mathrm{ng} \mathrm{g}^{-1}$. Such material was dominated by kaolinite minerals. These results show that the contribution of $\mathrm{Hg}$ bound to the organic fraction is significant compared to the total $\mathrm{Hg}$ content ${ }^{39}$.

Results for the determination of thermospecies of $\mathrm{Hg}$ in coal.. The procedure for determination of thermospecies of $\mathrm{Hg}$ developed by Mashyanov et al., $2007^{40}$ demonstrated good reproducibility of results at over selected temperature intervals, as noted in Fig. 3. After analysis of all samples for the presence of $\mathrm{Hg}$ peaks, it was established that some coal samples may contain only one $\mathrm{Hg}$ species, as indicated by the presence of only a single peak over the full temperature range investigated, whereas other samples may contain two to four peaks that are associated with different chemical forms of $\mathrm{Hg}$ in the coal specimen (cf. Fig. 3). The total concentration ( $\mathrm{ng} \mathrm{g}^{-1}$ ) and percentage (\%) of various thermospecies of $\mathrm{Hg}$ in selected samples from each of the South African provinces are shown in Table 5. These include coal samples with the smallest, close to the mean, and highest concentrations of $\mathrm{Hg}$. It was found that out of twenty one (21) analysed bituminous coal samples (excluding pyrite coals and SARM 20), sixteen (16) coal samples or $76 \%$ coal samples contained thermospecies of $\mathrm{Hg}$ that are released 


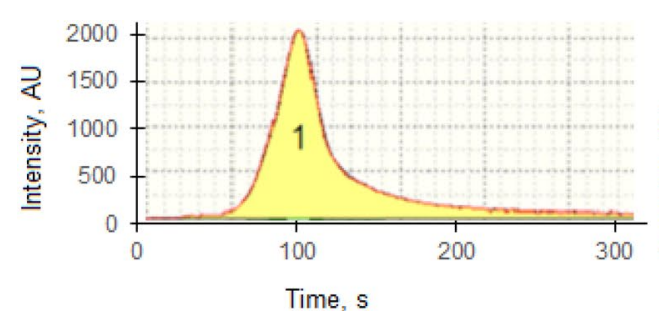

(a)

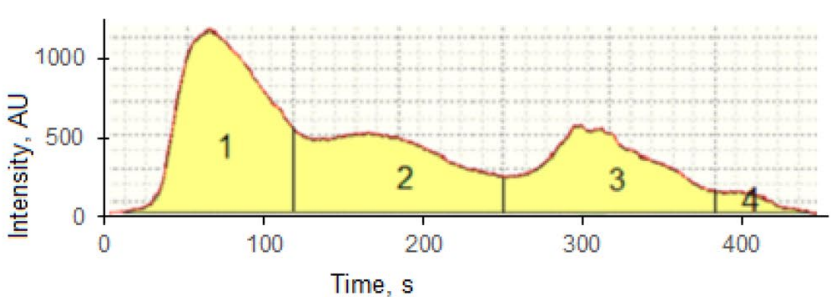

(b)

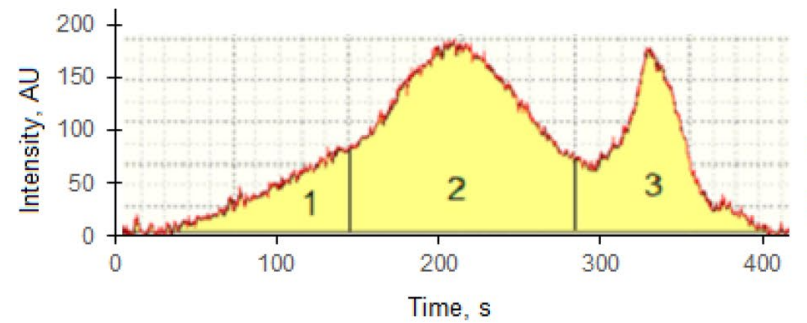

(c)

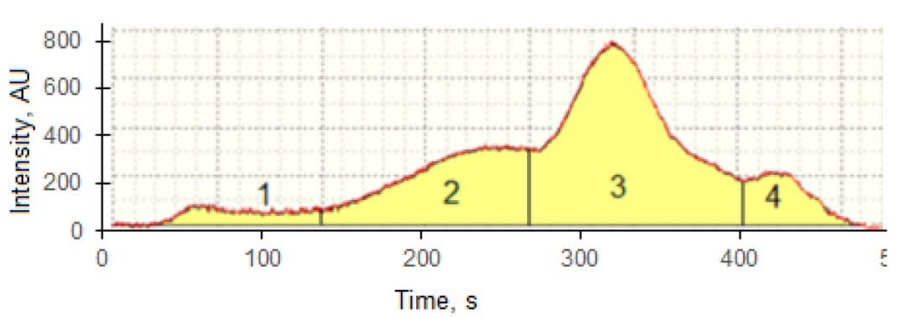

(d)

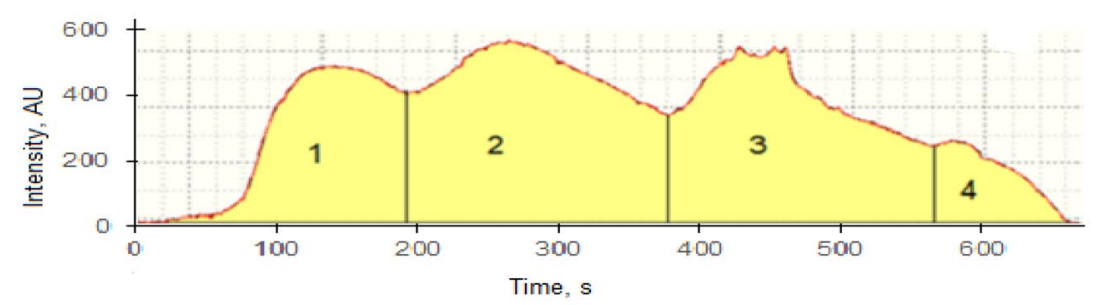

(e)

Figure 3. Examples of $\mathrm{Hg}$ thermospecies in South African coals: (a) coal with one low temperature thermo peak; (b) coal with multiple thermos species dominated with low temperature peak; (c) coal with three thermos peaks dominated with middle temperature peak; (d) coal with four thermospecies dominated with high temperature volatization; (e) coal with thermos species which volatile at all temperatures.

in a low temperature interval of $180^{\circ}$ to $360^{\circ} \mathrm{C}$, suggesting that this is elemental $\mathrm{Hg}^{0}$ and/or $\mathrm{Hg}$ associated with organic compounds ${ }^{41}$.

\section{Discussion}

Results of this investigation indicate that correct measurement of total Hg concentration in coal samples after thermal evaporation is constrained by achieving a number of conditions. One of them is the nature of the distribution of $\mathrm{Hg}$ in the coal which influence the reproducibility of determination of total $\mathrm{Hg}$. In the case of a homogeneous distribution, the particle size is not an important factor, but if this is not satisfied and $\mathrm{Hg}$ is present in the form of minerals such as cinnabar ( $\mathrm{HgS}$ ) or other compounds high in $\mathrm{Hg}$ concentration, the RSD of results can be very high, leading to poor precision. Thus, analysis of coal samples having an uneven distribution of $\mathrm{Hg}$ present in particle sizes ranging from 1000 to $3000 \mu \mathrm{m}$ could result in RSDs as high as $40 \%$, whereas when using pulverized coal having particle sizes below $50 \mu \mathrm{m}$ yields only $2 \%$ (cf Table 1 ). The extremely uneven distribution of $\mathrm{Hg}$ in samples from Vaal coal mine (northern Free State) could be connected with the geologic structure of the seam, wherein a combination of chemical and physical weathering has resulted in a highly undulating floor ${ }^{33}$. To achieve higher accuracy and precision, it is recommended that all coal samples be ground before analysis.

Another possible factor affecting reproducibility and accuracy of results during Hg determination in coal could be associated with sample mass taken for analysis. This study revealed that the Hg concentration in coal standard SARM 20 and coal G-1 derived from sample masses ranging from 50 to $300 \mathrm{mg}$ were identical at the $95 \%$ level of confidence (Table 2). The mean total Hg in SARM 20 was determined to be $250 \pm 5 \mathrm{ng} \mathrm{g}^{-1}$, in agreement with the certified value of $250 \pm 10 \mathrm{ng} \mathrm{g}^{-1}$. The total concentration of $\mathrm{Hg}$ in coal G-1 was $432 \pm 5 \mathrm{ng} \mathrm{g}^{-1}$, independent of sample mass in the range 50-300 mg, yielding an RSD of $1.0 \%$. These data show that results for determination of $\mathrm{Hg}$ in coals are not influenced by mass of sample taken for analysis.

The last factor which can influence the results is the stability of $\mathrm{Hg}$ as regards evaporation from the samples. Stability of thermos peaks of $\mathrm{Hg}$ could be identified by the shape of resultant absorbance signals recorded during analysis (cf Fig. 1). Various shapes were obtained are shown in Fig. 3. They reflect the presence of different modes of occurrence of $\mathrm{Hg}$ in coals. Detailed studies of $\mathrm{Hg}$ thermo peaks indicate that coal contains various forms of $\mathrm{Hg}$ that are released over specific temperature ranges, viz., $20-180{ }^{\circ} \mathrm{C}, 180-360{ }^{\circ} \mathrm{C}, 360-540{ }^{\circ} \mathrm{C}, 540-700{ }^{\circ} \mathrm{C}$, generating very stable and reproducible results, as summarized in Table 5. 


\begin{tabular}{|c|c|c|c|c|c|c|}
\hline \multirow[b]{2}{*}{ Province and coalfield } & \multirow[b]{2}{*}{ Sample identity number } & \multirow[b]{2}{*}{ Total $\mathrm{Hg}, \mathbf{n g ~ g}^{-1}$} & \multicolumn{4}{|c|}{$\begin{array}{l}\text { Hg thermospecies evaporated at specific temperature } \\
\text { intervals, \% }\end{array}$} \\
\hline & & & $20-180^{\circ} \mathrm{C}$ & $180-360^{\circ} \mathrm{C}$ & $360-540{ }^{\circ} \mathrm{C}$ & $540-720^{\circ} \mathrm{C}$ \\
\hline \multirow{3}{*}{ Limpopo, Waterberg } & L1 & 38 & 100 & - & - & - \\
\hline & L2 & 106 & 8 & 75 & 15 & - \\
\hline & L3 & 148 & 26 & 72 & 2 & - \\
\hline \multirow{3}{*}{ Mpumalanga, Witbank } & M2 & 15 & 100 & - & - & - \\
\hline & M6 & 150 & 34 & 66 & - & - \\
\hline & M14 & 467 & 23 & 43 & 23 & 11 \\
\hline \multirow{3}{*}{ Mpumalanga, Highveld } & MH3 & 142 & 30 & 49 & 22 & - \\
\hline & MH5 & 165 & 30 & 52 & 20 & 2 \\
\hline & MH7 & 183 & 66 & 20 & 19 & - \\
\hline \multirow{3}{*}{ Gauteng } & G2 & 35 & 100 & - & - & - \\
\hline & G4 & 174 & 88 & 12 & - & - \\
\hline & G5 & 210 & 25 & 65 & 10 & - \\
\hline \multirow{3}{*}{ Free State, New Vaal } & FS1 & 66 & 94 & 6 & & - \\
\hline & FS5 & 270 & 87 & 10 & 1 & - \\
\hline & FS7 & 448 & 75 & 13 & 11 & 5 \\
\hline \multirow{3}{*}{ KwaZulu-Natal } & KZ2 & 32 & 100 & - & - & - \\
\hline & KZ3 & 100 & 78 & 20 & 2 & - \\
\hline & KZ5 & 114 & 85 & 6 & 14 & - \\
\hline \multirow{3}{*}{ Eastern Cape, Ecca } & EC5 & 37 & 100 & - & - & - \\
\hline & EC8 & 74 & 55 & 45 & - & - \\
\hline & EC12 & 100 & 50 & 50 & - & - \\
\hline \multirow{3}{*}{ Selected samples } & SARM 20 & 250 & 68 & 31 & - & - \\
\hline & Pyrite & 542 & 41 & 24 & 31 & 3 \\
\hline & Pyrite sink & 1366 & 47 & 28 & 18 & 7 \\
\hline
\end{tabular}

Table 5. Concentration (ng g ${ }^{-1}$ ) and percentage (\%) of $\mathrm{Hg}$ thermospecies in coals of South African Provinces.

The mean Hg concentration in coals of South African Provinces was found to be $150 \pm 53 \mathrm{ng} \mathrm{g}^{-1}$ while the global average $\mathrm{Hg}$ content of coal, expressed on a whole-coal basis (the Clarke value for $\mathrm{Hg}$ in coal) is $100 \pm 10 \mathrm{ng} \mathrm{g}^{-1}$ and is the same for bituminous, subbituminous, and lignite rank coals. This result confirms previous findings that concluded that the mean value of $\mathrm{Hg}$ in South African coals is higher than the global average ${ }^{42}$.

Analysis of density fractionated coal samples showed that such samples can be used to identify the coal fraction that concentrates the $\mathrm{Hg}$ (cf Table 4). In general, it was found that in some coal samples, $\mathrm{Hg}$ accumulates in organic compounds in low density coal fractions whereas in other samples of coal $\mathrm{Hg}$ is concentrated in the mineral sink and the highest content found was $1340 \pm 35 \mathrm{ng} \mathrm{g}^{-1}$ in contrast to mineral bound coal fractionated sink sample of batch $1\left(79 \pm 2 \mathrm{ng} \mathrm{g}^{-1}\right)$. The results of pyrolysis of the density-fractionated samples lead to the conclusion that the method of thermal speciation is more efficient for the selection of coal for Hg removal by mild pyrolysis before coal combustion. Thermospeciation of $\mathrm{Hg}$ in coal prevents direct application of pyrolysis technology to raw unsuitable coal with a high content of pyrite-bound $\mathrm{Hg}$ because the high pyrolysis temperature demands high energy consumption, thereby degrading overall coal heating efficiency.

In spite of the fact that most of South African coals are bituminous grade, $2 \%$ being anthracite grade and $1.6 \%$ being coal of metallurgical quality, several thermospecies of $\mathrm{Hg}$ were detected in most coal samples due to their different binding energy to coal matrix.

Coal may contain one or several Hg species that are released at variable temperatures (cf Table 5). The majority of such species were released in the range $20-180^{\circ} \mathrm{C}$ and can be attributed to elemental $\mathrm{Hg}$ as it is known to be vaporized in this range of temperature. The second dominant thermospecies, released between $180^{\circ} \mathrm{C}$ and $360^{\circ} \mathrm{C}$, could be connected to the presence of organobound- $\mathrm{Hg}$ compounds, whereas the least amount of $\mathrm{Hg}$ is released between 360 and $540{ }^{\circ} \mathrm{C}$ and may be connected with a pyrite bound $\mathrm{Hg}$ fraction ${ }^{46}$. Identification of the volatility temperature range of $\mathrm{Hg}$ in coal in advance of use is a necessary step required to select an appropriate method for removal of $\mathrm{Hg}$ during coal combustion for electricity generation.

\section{Conclusions}

This study shows that the accuracy and precision of determination of total $\mathrm{Hg}$ in coals having an inhomogeneous distribution of $\mathrm{Hg}$ is dependent on the particle size of the samples taken for analysis. Particle sizes below $50 \mu \mathrm{m}$ are recommended for analysis to ensure accurate and precise results. It was also found that the results of analysis are independent of the mass of the samples in the range of 50-300 mg. Results for determination of total $\mathrm{Hg}$ show that the mean value of $\mathrm{Hg}$ concentration in coal samples from all South African Provinces is on the level of $150 \pm 53 \mathrm{ng} \mathrm{g}^{-1}$. 
The presence of $\mathrm{Hg}$ species of various thermal stability in coal was demonstrated through detection of multiple desorption peaks, dominated by low temperature evaporation of elemental $\mathrm{Hg}$ released at $20-180{ }^{\circ} \mathrm{C}$. The specific temperature range of $\mathrm{Hg}$ peaks creates a basis for selection of coals for preliminary cleaning prior combustion at electrical power stations according to the thermal stability of the $\mathrm{Hg}$ species. Identification of thermospecies is an analytical problem that requires further studies.

Analysis of density fractionated coal samples showed that $\mathrm{Hg}$ can be concentrated in both organic components of coals, as well as in mineral fractions. This study presents new insights into our knowledge of the forms of $\mathrm{Hg}$ present in South African coals.

Received: 4 July 2020; Accepted: 19 October 2020

Published online: 06 November 2020

\section{References}

1. Sundseth, K., Pacyna, J. M. E. G., Pirrone, N. \& Thorne, R. J. Global sources and pathways of mercury in the context of human health. Int. J. Environ. Res. Public Health. 14, 105-118 (2017).

2. EPA US. https://www.epa.gov/mercury/basic-information-about-mercury (2019).

3. Raj, D. \& Maiti, S. K. Sources, toxicity, and remediation of mercury: An essence review. Environ. Monit. Assess 191, 566-588 (2019).

4. Landing, W.M. \& Holmes, C.D. Overview of the atmospheric mercury cycle. in (Pollman, C.D., Rumbold, D.G. \& Axelrad, D.M. eds.) Mercury and the Everglades. A Synthesis and Model for Complex Ecosystem Restoration, Volume 1: The Evolution of the Everglades as a Perturbed Ecosystem and the Role of Atmospheric Mercury 47-59 (2019).

5. UNEP (United Nations Environmental Programme). Global Mercury Assessment: Sources, Emissions, Releases and Environmental Transport. (UNEP Chemicals Branch, Geneva, 2018).

6. Shahid, N. M. et al. A critical review of mercury speciation, bioavailability, toxicity and detoxification in soil-plant environment: Ecotoxicology and health risk assessment. Sci. Total Environ. 711, 134749 (2020).

7. Streets, D. G. et al. All-time releases of mercury to the atmosphere from human activities. Environ. Sci. Technol. 45, 10485-10491 (2011).

8. Zhao, S., Pudasainee, D, Duan, Y., Gupta, R., Liu, M. \& Lu, J. A review on mercury in coal combustion process: Content and occurrence forms in coal, transformation, sampling methods, emission and control technologies, Prog. Energy Combust. Sci. 73, 26-64 (2019).

9. Hu, J., Sun, Q. \& Zhang, J. H. Critical temperature for rapid release of mercury from coal after high temperature: A review. J. Clean. Prod. 267, 122166 (2020).

10. Minamata disease, 2020. https://en.wikipedia.org/wiki/Minamata_disease.

11. Minamata Convention. Special High-Level Event to Foster Entry into Force and Implementation of the Minamata Convention, 24 September 2015, New York, USA.

12. E3S Web of Conferences 28. Ewa Strzelecka-Jastrząb Minamata Convention on Mercury. Reporting Obligations of the Parties to the Convention and the Sources of Data Existing in Poland, Air Protection in Theory and Practice, https://doi.org/10.1051/e3sconf/20182 801035 (2018)

13. Streets, D. G., Lu, Z., Levin, L., Schue, A. F. H. \& Sunderland, E. M. Historical releases of mercury to air, land, and water from coal combustion. Sci. Total Environ. 615, 131-140 (2018).

14. Hu, Y. \& Cheng, H. Control of mercury emissions from stationary coal combustion sources in China: Current status and recommendations. Environ. Pollut. 218, 1209-1221 (2016).

15. Demper, J. Eskom Perspectives: Expansion of Power Generation in the Waterberg. Influence of Waterberg Coal Qualities on Matimba Boilers. Presented at the Fossil Fuel Foundation of South Africa Conference: The Waterberg Coalfield 2006 and Beyond-Quo vadis, Ellisras (2006).

16. Pacyna, E. G., Pacyna, J. M., Steenhuisen, F. \& Wilson, S. Global anthropogenic mercury emission inventory for 2000. Atmos. Environ 40, 4048-4063 (2006).

17. Dabrowski, J. M., Ashton, P. J., Murray, K., Leaner, J. J. \& Mason, R. P. Anthropogenic mercury emissions in South Africa: Coal combustion in power plants. Atmos. Environ. 42, 6620-6626 (2008).

18. Masekoameng, E. K., Learner, J. \& Dabrowski, J. Trends in anthropogenic mercury emissions estimated for South Africa during 2000-2006. Atmos. Environ. 44, 3007-3014 (2010).

19. Garnham, B. L. \& Langerman, K. E. Mercury emissions from South Africa's coal-fired power stations. Clean Air J. 26, 14-16 (2016).

20. Zhang, H. et al. Mercury distribution in bituminous coal and its releasing behaviour during mild pyrolysis process. Fuel Process. Technol. 185, 38-45 (2019).

21. Guffey, F. D. \& Bland, A. E. Thermal pretreatment of low-ranked coal for control of mercury emissions. Fuel Process. Technol. 85, 521-531 (2003).

22. Minami, W., Xu, Z. \& Kim, H. Mercury removal characteristics during thermal upgrading of fractionated Alberta subbituminous coal. Energ Fuel 21, 3607-3611 (2007).

23. Marczak, M. et al. Active methods of mercury removal from flue gases. Environ. Sci. Pollut. Res. 26, 8383-8392 (2019).

24. Luo, G. et al. Hg occurrence in coal and its removal before coal utilization. Fuel 104, 70-76 (2013).

25. Chmielniak, T., Slowik, K. \& Sajak, M. Mercury removal by mild thermal treatment of coal. Fuel 195, 290-298 (2017).

26. Lwashita, A., Tanamachi, S., Nakajima, T., Takanashi, H. \& Ohki, A. Removal of mercury from coal by mild pyrolysis and leaching behaviour of mercury. Fuel 83, 631-638 (2004).

27. Sotiropoulou, R. E. P., Serafidou, M. \& Skodras, G. Thermal mercury removal from coal: Effects of pyrolysis conditions and kinetic analysis. Fuel 238, 44-50 (2019).

28. Zhao, S. \& Alexandroff, A. Current and future struggles to eliminate coal. Energy Policy 129, 511-520 (2019).

29. Sholupov, S., Pogarev, V. Ryzhov, N., Mashyanov, \& Stroganov, A. Zeeman atomic absorption spectrometer RA- 915 for direct determination of mercury in air and complex matrix samples. Fuel Process. Technol. 85, 473-485 (2004).

30. Sholupov, S. \& Ganeev, A. Zeeman atomic absorption spectrometry using high frequency modulated light polarization. Spectrochim. Acta. Part B 50, 1227-1236 (1995).

31. ASTM (American Society for Testing and Materials) ASTM D2013: Standard Practice for Preparing Coal Samples for Analysis (2011).

32. Peatfield, D. Coal and coal preparation in South Africa-A 2002 review. J. S. Afr. I. Min. Metall. 103, 355-372 (2003).

33. Jeffery, L. S. Characterization of the coal resources of South Africa. J. S. Afr. I. Min. Metall. 105, 95-102 (2005).

34. Hancox, P. J. \& Götz, A. E. South Africa's coalfields-2014 perspective. Int. J. Coal. Geol. 132, 170-254 (2014).

35. Miller, J. N. \& Miller, J. C. Statistics and Chemometrics for Analytical Chemistry 5th edn. (Pearson Education Limited, London, 2005).

36. Wagner, J. N. \& Hlatshwayo, B. The occurrence of potential hazardous trace element in five Highveld coal, South Africa. Int. J. Coal Geol 63, 228-246 (2005). 
37. Bergh, J. P. Trace Elements Partitioning in the Witbank Coalfield 4 Seam (Paper: Fossil Fuel Foundation Indaba, Johannesburg, 2009).

38. Wagner, J. N. \& Tlotleng, M. T. Distribution of selected traces elements in density fractionated Waterberg coal from South Africa. Int. J. Coal Geol 94, 225-237 (2012).

39. Yudovich, Y. E. \& Ketris, M. P. Mercury in coal: A review: Part 1, Geochemistry. Int. J. Coal Geol. 62, 107-134 (2005).

40. Mashyanov, N. R., Pogarev, S. E., Panova, E. G., Panichev, N. \& Ryzhov, V. Determination of mercury thermospecies in coal. Fuel 203, 973-980 (2017).

41. Luo, G., Yao, H., Xu, M., Gupta, R. \& Xu, Z. Identifying modes of occurrence of mercury in coal by temperature programmed pyrolysis. Proc. Combust. Inst. 33, 2763-2769 (2011).

42. Lusilao-Makiese, J., Tessier, E., Amouroux, D., Tutu, H., Chimuka, L. \& Cukrowska, E.M. Speciation of mercury in South African coals. Toxicol. Environ. Chem. 94, 1688-1706 (2012).

\section{Acknowledgements}

The authors acknowledge Prof JN Wagner (University of Johannesburg) for supplying us with coal samples and the National Research Foundation of South Africa and the Russian Foundation for Basic Research, Joint Science and Technology Cooperation in Basic Research, Project № 14-05-93961 for funding the research project.

\section{Author contributions}

The roles of each authors in this submission are summarized below: M.W.M. (Postgraduate student): Method development and analysis of coal samples. N.P.: Conception of the project, Co-supervision of the project, Visualization, Review and editing of the project. K.L.M.: Project administration, Resources, Supervision of the project, Review and editing of the project.

\section{Competing interests}

The authors declare no competing interests.

\section{Additional information}

Correspondence and requests for materials should be addressed to K.M.

Reprints and permissions information is available at www.nature.com/reprints.

Publisher's note Springer Nature remains neutral with regard to jurisdictional claims in published maps and institutional affiliations.

(c) (i) Open Access This article is licensed under a Creative Commons Attribution 4.0 International License, which permits use, sharing, adaptation, distribution and reproduction in any medium or format, as long as you give appropriate credit to the original author(s) and the source, provide a link to the Creative Commons licence, and indicate if changes were made. The images or other third party material in this article are included in the article's Creative Commons licence, unless indicated otherwise in a credit line to the material. If material is not included in the article's Creative Commons licence and your intended use is not permitted by statutory regulation or exceeds the permitted use, you will need to obtain permission directly from the copyright holder. To view a copy of this licence, visit http://creativecommons.org/licenses/by/4.0/.

(C) The Author(s) 2020 